\title{
Development and validation of spectrophotometric methods for the quantification of solifenacin succinate: application to tablet dosage forms
}

\author{
Burla Sunitha Venkata Seshamamba ${ }^{1, *}$, Peruri Veera Venkata Satyanarayana ${ }^{2}$, \\ Chandra Bala Sekaran ${ }^{3}$ \\ ${ }^{1}$ Department of Food Chemistry and Nutrition, College of Food Science and Technology, \\ Bapatla, Andhra Pradesh - 522101, India \\ ${ }^{2}$ Department of Biochemistry, Acharya Nagarjuna University, Guntur, Andhra Pradesh - 522510, India \\ ${ }^{3}$ Department of Biotechnology, Jagarlamudi Kuppuswamy Choudary College, \\ Guntur, Andhra Pradesh - 522006, India \\ *E-mail address: sunithafst@gmail.com
}

\begin{abstract}
Four sensitive, precise and accurate spectrophotometric methods for the estimation of solifenacin succinate (SFS) have been developed. Method A describes the interaction of SFS with potassium permanganate in alkaline medium to give green colored manganate ion with absorption maxima at $610 \mathrm{~nm}$. Methods $\mathrm{B}$ and $\mathrm{C}$ are based on the formation of ternary complexes of SFS with, copper (II)/eosin (method B) and ammonium molybdate/ammonium thiocyanate (method C), respectively which are extracted into chloroform and have absorption maxima at $545 \mathrm{~nm}$ (method B) and $465 \mathrm{~nm}$ (method C). Method D was based on the formation of yellow colored ion-pair complex between bromocresol green and SFS in dichloromethane medium with absorption maxima at $415 \mathrm{~nm}$. Regression analysis of Beer's law plot showed good correlation in the concentration range of 5-50, 2.5-50, 10-100 and 2-20 $\mu \mathrm{g} / \mathrm{mL}$ for methods A, B, C and D, respectively. Different variables affecting the reaction were studied and optimized. The proposed methods were applied successfully for the analysis of SFS in tablets dosage forms. No interference was observed from common pharmaceutical excipients.
\end{abstract}

Keywords: Solifenacin succinate; potassium permanganate; copper sulphate; ammonium molybdate; bromocresol green

\section{INTRODUCTION}

Solifenacin succinate (SFS) [1-4], an antimuscarinic/anticholinergic muscle relaxant, used to reduce urinary frequency, urinary urgency and urinary incontinence in people with an over active bladder. SFA works by relaxing the involuntary detrusor muscle in the wall of the bladder by blocking muscarinic/cholinergic receptors present on the surface of the muscle cells and thus prevents acetylcholine from acting on these receptors. Chemically, SFS is known as 1-azabicyclo[2.2.2] oct-3-yl (1S)-1-phenyl-3,4-dihydro-1H-isoquinoline-2carboxylate (Fig. 1). 


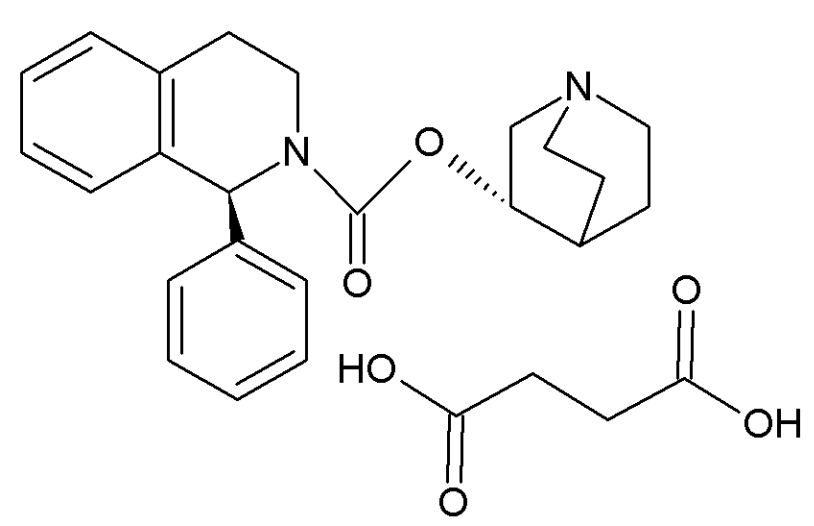

Fig. 1. Chemical structure of solifenacin succinate.

Chromatographic techniques such as high performance liquid chromatography $[5,6]$, stability indicating high performance liquid chromatography [7-9], stability indicating ultrafast liquid chromatography [10], semi-micro high performance liquid chromatography [11], liquid chromatography-tandem mass spectrometry[12,13], stability-indicating high performance thin layer chromatography [14,15] have been applied for the quantification of SFS in bulk, biological fluids and commercial formulations. Though the chromatographic methods are sensitive the instrumentations are burdensome and necessitate critical experimental conditions. Hence these techniques are not applied for routine analysis of SFS.

In view of the fact that spectrophotometric procedures are simple, fairly accurate \& precise and cost effective, they are still popular for the routine analysis in quality control laboratories. Seetharaman and Lakshmi have described first order derivative spectrophotometric method for the estimation of SFS in pharmaceutical formulation [16]. Singh \& Nanda [17] and Alia afra etal., [18] determined SFS in tablet formulations spectrophotometrically based on the ion pair complexation reaction of SFS with bromothymol blue, bromophenol blue and alizarin red. The reported spectrophotometric methods suffered from one or other disadvantage like poor selectivity, less sensitive and narrow range of linear response. Robustness was not reported in the spectrophotometric methods.

In the present work four sensitive visible spectrophotometric methods (A, B, C and D) have been developed and validated for the estimation of SFS in bulk and tablet dosage forms. The methods are based on the redox reaction between the SFS and potassium permanganate in alkaline medium [method A], on the formation of a chloroform extractable ternary complex between SFS, copper(II) and eosin [method B], on the formation of a chloroform extractable ternary complex between SFS, ammonium molybdate and ammonium thiocyanate [method C] and on the ion-pair complexation of SFS with bromocresol green in dichloromethane medium [method D].

Potassium permanganate is an oxidizing agent for many drugs in which green colored manganate ion $\left(\mathrm{MnO}_{4}{ }^{2-}\right)$ is formed. This reaction was used in the determination of many drug substances such as pipazethate $\mathrm{HCl}$ [19], dextromethorphan $\mathrm{HBr}$ [19], furosemide [20], tetracycline $\mathrm{HCl}$ [21] and oseltamavir phosphate [22].

Copper(II)/eosin and ammonium molybdate/ammonium thiocyanate are reagents specific for the formation of ternary complex with amine group containing drugs. Several pharmaceutical compounds have been determined through this approach, such as ramipril [23], enalpril [24], perindopril [25] and carbinoxamine maleate [26].

Bromocresol green is an ion-pair agent for many drugs with primary, secondary or tertiary amine in which a colored ion-pair complex is formed. Many drug substances such as 
dutasteride [27], atorvastatn [28], carvedilol [29], Trodat-1 hydrochloride [30], fluroquinolones [31] and tianeptine [32] have been determined on this basis.

The structural features of SFS allowed the use of the above four reagents for its assay.

\section{EXPERIMENTAL}

\section{1. Apparatus}

The spectrophotometric measurements were carried out using an Elico double beam model SL 159 digital spectrophotometer with 1-cm matched quartz cells.

\section{2. Reagents}

All the chemicals used were of analytical grade and doubly distilled water was used throughout. Aqueous solutions of $0.0015 \mathrm{M}$ potassium permanganate (Merck, Mumbai, India) and 0.6 M sodium hydroxide (Merck, Mumbai, India) were prepared for method A. For method B aqueous solutions of $0.3 \%$ copper sulphate (Fisher Scientific, Mumbai, India) and $0.1 \%$ eosin (Fisher Scientific, Mumbai, India) were prepared. To use in method C, $0.001 \mathrm{M}$ ammonium molybdate (Sdfine-Chem limited, Mumbai, India), $10 \%$ ammonium thiocyanate (Sdfine-Chem limited, Mumbai, India), $10 \%$ ascorbic acid (Sdfine-Chem limited, Mumbai, India) and $3 \mathrm{M} \mathrm{HCl}$ (Fisher Scientific, Mumbai, India) were prepared in double distilled water. Bromocresol green (Sdfine-Chem limited, Mumbai, India) was prepared as $0.01 \%$ in dichloromethane (Merck, Mumbai, India) for method D. Chloroform (Merck, Mumbai, India) was used for the extraction of ternary complexes in methods $\mathrm{B}$ and $\mathrm{C}$

\section{3. Standard solutions}

For methods A, B and C an accurately weighed amount (100 mg) of SFS was transferred into a $100 \mathrm{~mL}$ calibrated flask, dissolved in $50 \mathrm{~mL}$ distilled water, and completed to volume with the distilled water to produce a stock solution of $1 \mathrm{mg} / \mathrm{mL}$. The stock solution was then diluted with distilled water to get working standard solutions of $500 \mu \mathrm{g} / \mathrm{mL}$ for methods A \& C and $25 \mu \mathrm{g} / \mathrm{mL}$ for method B. For method D, stock standard solution of SFS containing $1 \mathrm{mg} / \mathrm{mL}$ was prepared in dichloromethane and was further diluted with the same solvent as to obtain a working standard solution of concentration $100 \mu \mathrm{g} / \mathrm{mL}$.

\section{4. General assay procedure}

\section{4. 1. Method A}

Increasing volumes $(0.1-1 \mathrm{~mL})$ from the working standard solution of the SFS were transferred to a set of $10 \mathrm{~mL}$ volumetric flasks, so as to contain the drug within the concentration range $5-50 \mu \mathrm{g} / \mathrm{mL}$. The total volume was adjusted to $1 \mathrm{~mL}$ with doubly distilled water. To each flask $2 \mathrm{~mL}$ of $0.0015 \mathrm{M} \mathrm{KMnO}_{4}$ followed by $2 \mathrm{~mL}$ of $0.6 \mathrm{M} \mathrm{NaOH}$ were added and then diluted to the mark with doubly distilled water. The solutions were mixed well and kept at room temperature for 20 minutes. The absorbance was measured at $610 \mathrm{~nm}$ against a reagent blank.

\section{4. 2. Method B}

Increasing volumes $(0.1-2 \mathrm{~mL})$ from the working standard solution of the SFS were transferred to a set of $100 \mathrm{~mL}$ separating funnels, so as to contain the drug within the 
concentration range $2.5-50 \mu \mathrm{g} / \mathrm{mL}$. The total volume was adjusted to $2 \mathrm{~mL}$ with doubly distilled water. To each separating funnel $2.5 \mathrm{~mL}$ of $0.3 \%$ copper sulphate followed by $1 \mathrm{~mL}$ of $0.1 \%$ eosin were transferred and mixed well. The funnels were shaken vigorously with 5 $\mathrm{mL}$ of chloroform for 2 minutes. The funnels were allowed to stand for clear separation of the two phases. The chloroform phase thus separated was transferred into a $10 \mathrm{~mL}$ volumetric flask. The extract was made up to the mark with chloroform and mixed well. The absorbance of the chloroform phase was measured at $545 \mathrm{~nm}$ against a reagent blank

\section{4. 3. Method C}

Increasing volumes $(0.1-2 \mathrm{~mL})$ from the working standard solution of the SFS were transferred to a set of $100 \mathrm{~mL}$ separating funnels, so as to contain the drug within the concentration range $10-100 \mu \mathrm{g} / \mathrm{mL}$. The total volume was adjusted to $2 \mathrm{~mL}$ with doubly distilled water. To each separating funnel $2.5 \mathrm{~mL}$ of $0.001 \mathrm{M}$ ammonium molybdate, $1 \mathrm{~mL} 3$ $\mathrm{M} \mathrm{HCl}, 1 \mathrm{~mL} 10 \%$ ascorbic acid solution and $2 \mathrm{~mL}$ of $10 \%$ ammonium thiocyanate were added and mixed well. The funnels were kept at room temperature for 10 minutes. The funnels were shaken vigorously with $5 \mathrm{~mL}$ chloroform for 2 minutes, and then allowed to stand for clear separation of the two phases. The separated organic phase was transferred to a $10 \mathrm{~mL}$ volumetric flask, made up to the mark with chloroform and mixed well. The absorbance of the chloroform phase was measured at $465 \mathrm{~nm}$ against a reagent blank.

\section{4. 4. Method D}

Increasing volumes $(0.2-2 \mathrm{~mL})$ from the working standard solution of the SFS were transferred to a set of $10 \mathrm{~mL}$ volumetric flasks, so as to contain the drug within the concentration range $2-20 \mu \mathrm{g} / \mathrm{mL}$. The total volume was adjusted to $2 \mathrm{~mL}$ with dichloromethane. To each flask $1 \mathrm{~mL}$ of $0.01 \%$ bromocresol green was added, diluted to the mark with dichloromethane and then mixed well. The absorbance was measured at $415 \mathrm{~nm}$ against a reagent blank.

In all the above procedures, the calibration graphs were constructed by plotting the final concentration of the SFS in $\mu \mathrm{g} / \mathrm{mL}$ versus the absorbance values. The amount of the SFS was computed either from the calibration graph or from the regression equation.

\section{5. Procedure for assay of SFS in tablets}

The commercial tablet dosage forms of SFS, Solicin (Ranbaxy Laboratories Limited, Solan, India), were purchased from a local pharmacist. Twenty tablets were accurately weighed and ground into fine powder. A portion of tablet powder equivalent to $50 \mathrm{mg}$ of SFS was weighed into a $50 \mathrm{~mL}$ beaker, $30 \mathrm{~mL}$ of water was added and the mixture was shaken for 20 minutes. The mixture was filtered into $50 \mathrm{~mL}$ volumetric flask through Whatman No. 1 filter paper.

The solution was made up to the mark with doubly distilled water to obtain a stock solution with a concentration of $1 \mathrm{mg} / \mathrm{mL}$. The stock solution was then diluted with distilled water to get working standard solutions of $500 \mu \mathrm{g} / \mathrm{mL}$ (methods A \& C) and $25 \mu \mathrm{g} / \mathrm{mL}$ (method B). Suitable aliquot was then subjected to the analysis using the procedure described under methods A, B and C. Another portion of tablet powder equivalent to $25 \mathrm{mg}$ of SFS was accurately weighed into a $25 \mathrm{~mL}$ beaker, $15 \mathrm{~mL}$ of dichloromethane was added and shaken for 20 minutes. The solution was filtered into a $25 \mathrm{~mL}$ of volumetric flask through Whatmann No 1 filter paper and was diluted to the volume with dichloromthane, to obtain a stock solution with a concentration of $1 \mathrm{mg} / \mathrm{mL}$. The stock solution was diluted appropriately with 
dichloromethane to obtain a working standard solution of $100 \mu \mathrm{g} / \mathrm{mL}$. Convenient aliquot was subjected to analysis by the procedure described under method $\mathrm{D}$.

\section{RESULTS AND DISCUSSION}

\section{1. Absorption maxima of the colored products}

The absorption maxima of the colored products formed in methods A, B, C and D were determined by scanning them in the wavelength region of $400-700 \mathrm{~nm}$ against a corresponding reagent blank. The absorption maxima of the colored products were found to be 610, 465 and $415 \mathrm{~nm}$ for methods A, C, and D, respectively (Fig. 2). In method B, the colored product exhibited two peaks, one at $460 \mathrm{~nm}$ and another at $545 \mathrm{~nm}$.

The sensitivity and linearity of the method B was good at $545 \mathrm{~nm}$. So $545 \mathrm{~nm}$ was chosen as the absorption maxima for the method B (Fig. 2). Under the optimized experimental conditions reagent blank of methods $\mathrm{A}, \mathrm{B}, \mathrm{C}$ and $\mathrm{D}$ showed insignificant absorbance at the corresponding optimum wavelength.

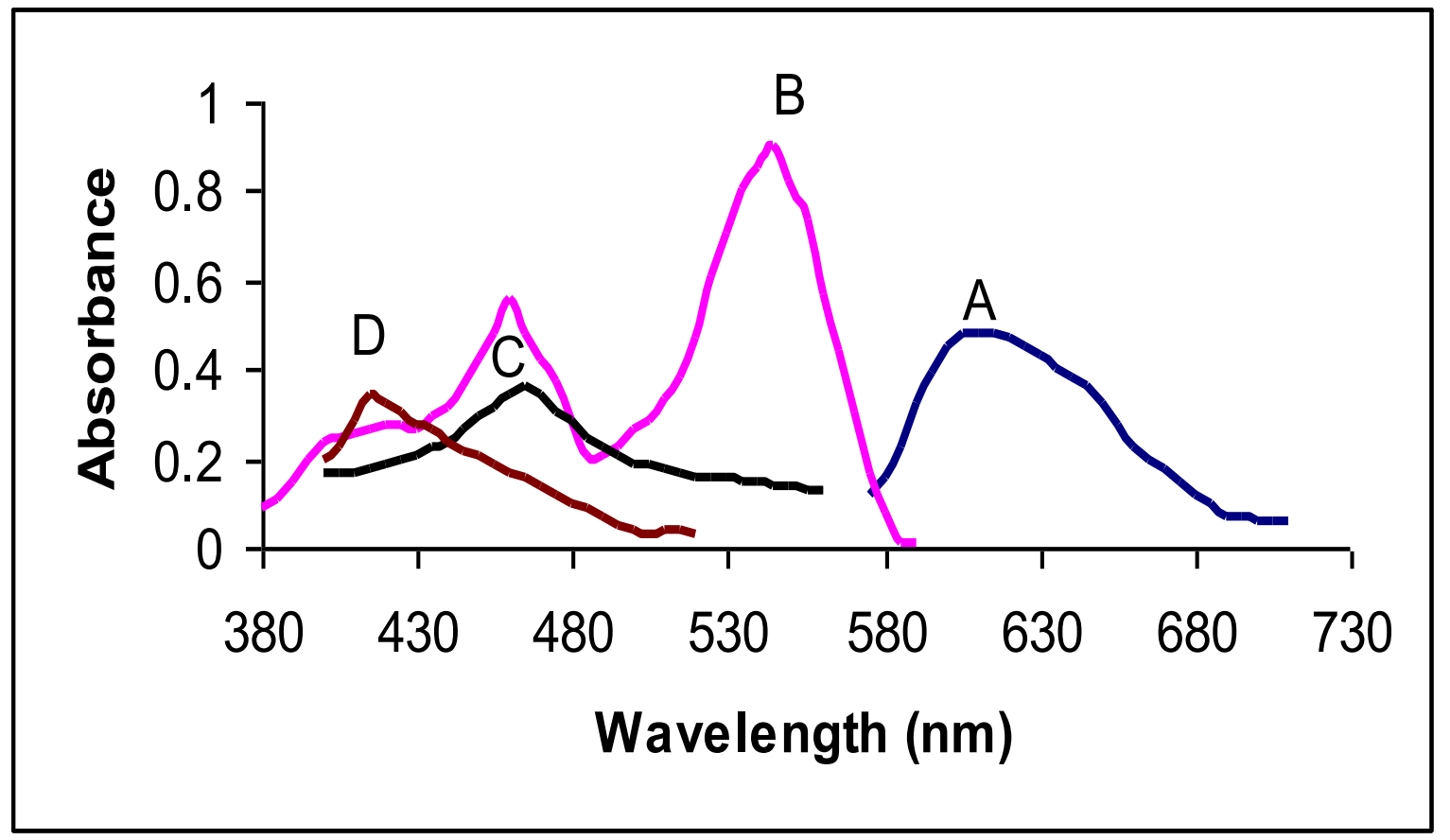

Fig. 2. Absorption spectra of: $A)$ Green colored manganate ion $\left.\left(\lambda_{\max } 610 \mathrm{~nm}\right), B\right)$ red colored SFS-Cu(II)-eosin ternary complex $\left.\left(\lambda_{\max } 545 \mathrm{~nm}\right), C\right)$ Reddish yellow colored SFS-Mo(SCN $)_{6}^{-}$ ternary complex $\left.\left(\lambda_{\max } 465 \mathrm{~nm}\right), D\right)$ Yellow colored SFS-bromocresol green ion-pair complex

$$
\left(\lambda_{\max } 415 \mathrm{~nm}\right)
$$

\section{2. Chemistry of the colored products}

\subsection{Method A}

In method $\mathrm{A}$, the results obtained were due to the formation of green colored manganate ion $\left(\mathrm{MnO}_{4}{ }^{2-}\right)$, as a result of redox reaction between $\mathrm{KMnO}_{4}$ by SFS in alkaline medium. The 
amount of manganate ions formed corresponds to the amount of SFS. This has been the basis for the determination of SFS in pure and in tablet dosage forms by method A.

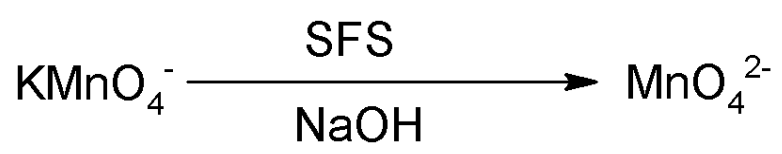

\section{2. 2. Method B}

In method B, the results obtained were based on formation of ternary complex between the SFS, eosin and copper sulphate, which is extractable with chloroform from the aqueous phase, resulting in formation of a red color solution. This has been the basis for the determination of SFS in pure and in tablet dosage forms by method B. The possible reaction pathway is shown in Fig. 3.<smiles>O=C(O)CCC(=O)O</smiles>

Solifenacin succinate<smiles>O=C(O)c1ccccc1-c1c2cc(Br)c(=O)c(Br)c-2oc2c(Br)c(O)c(Br)cc12</smiles>

Eosin

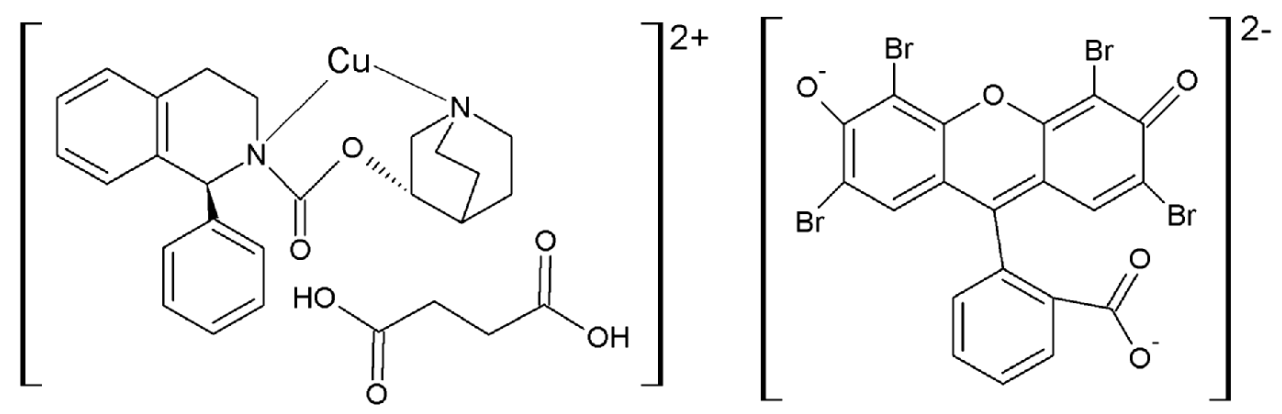

Red colored ternary complex

Fig. 3. Proposed reaction mechanism for the formation of SFS-Cu(II)-Eosin ternary complex.

\section{2. 3. Method C}

In method $\mathrm{C}$, the results obtained were due to the formation of ternary complex between the SFS and molybdenum(V)thiocyanate binary complex $\left[\mathrm{Mo}(\mathrm{SCN})_{6}{ }^{-}\right]$. $\mathrm{Mo}(\mathrm{SCN})_{6}{ }^{-}$binary complex was formed as the result of reduction of $\mathrm{Mo}(\mathrm{VI})$ by ascorbic acid in acidic medium 
followed by its reaction with thiocyanate. Ascorbic acid also enhances the sensitivity and stability of the $\mathrm{Mo}(\mathrm{SCN})_{6}{ }^{-}$binary complex. In acidic media, the secondary amine group of SFS gets protonated. The protonated form of SFS forms ternary complex with $\mathrm{Mo}(\mathrm{SCN})_{6}^{-}$ binary complex, which is extractable with chloroform from the aqueous phase, resulting in formation of a reddish yellow color solution. The possible reaction pathway is shown in Fig. 4
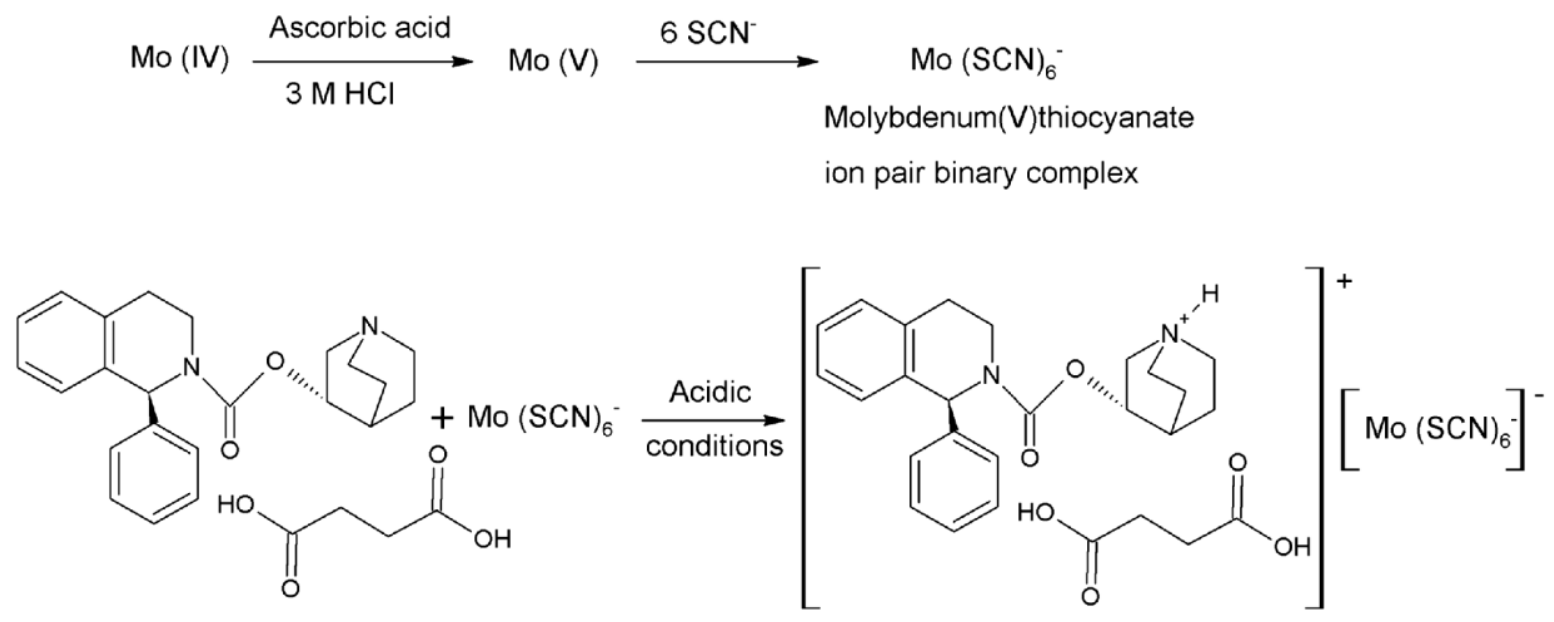

Reddish yellow colored ternary complex

Fig. 4. Proposed reaction mechanism for the formation of SFS-Mo(SCN $)_{6}{ }^{-}$ternary complex.

\section{2. 4. Method D}

In method D, the results obtained were due to the formation of yellow colored ion-pair complex between SFS and bromocresol green in dichloromethane medium. During the reaction process the lactoid ring of bromocresol green opens to form a quinoidal anionic derivative. The tertiary amine group of SFS was protonated by the protons released during the opening of lactoid ring. Finally, the quinoidal anionic derivative forms ion-pair with protonated form of SFS. The possible reaction pathway is shown in Fig. 5.

\section{3. Optimization of the experimental variables}

The experimental variables were optimized by varying one variable and observing its effect on the absorbance of the colored products. The optimized conditions were throughout the experiments.

\section{3. 1. Method A}

The reaction was studied under various conditions of $\mathrm{KMnO}_{4}$ and $\mathrm{NaOH}$ concentration. The effect of the concentration of $\mathrm{KMnO}_{4}$ was studied by treating $25 \mu \mathrm{g} / \mathrm{mL}$ SFS with varying volumes $(0.5-3 \mathrm{~mL})$ of $0.0015 \mathrm{M} \mathrm{KMnO}_{4}$ and $2 \mathrm{~mL}$ of $0.6 \mathrm{M} \mathrm{NaOH}$. The absorbance of green colored product at $610 \mathrm{~nm}$ was increased with increasing volume of $\mathrm{KMnO}_{4}$ upto $2 \mathrm{~mL}$; above this volume, the absorbance decreased. Therefore, $2 \mathrm{~mL}$ of $0.0015 \mathrm{M} \mathrm{KMnO}_{4}$ was used in all the measurements.

The influence of the concentration of $\mathrm{NaOH}$ on the absorbance at $610 \mathrm{~nm}$ was investigated by treating $25 \mu \mathrm{g} / \mathrm{mL}$ SFS with $2 \mathrm{~mL}$ of $0.0015 \mathrm{M} \mathrm{KMnO}_{4}$ and varying volumes 
(0.5-3 mL) of $0.6 \mathrm{~m} \mathrm{NaOH}$. The absorbance was increased with increasing volume of $\mathrm{NaOH}$ and became constant at $2 \mathrm{~mL}$; beyond this volume, the absorbance remained constant. Therefore $2 \mathrm{~mL}$ of $0.6 \mathrm{~m} \mathrm{NaOH}$ was suggested for the determination procedures.

To investigate the optimum reaction time for the color development, the contents of the reaction mixture $\left(25 \mu \mathrm{g} / \mathrm{mL}\right.$ SFS, $2 \mathrm{~mL}$ of $0.0015 \mathrm{M} \mathrm{KMnO}_{4}$ and $2.0 \mathrm{~mL}$ of $\left.0.6 \mathrm{~m} \mathrm{NaOH}\right)$ were kept at room temperature for 5-30 min. The maximum intensity of color was obtained at $20 \mathrm{~min}$. Therefore, $20 \mathrm{~min}$ of reaction time was used throughout the experiments.
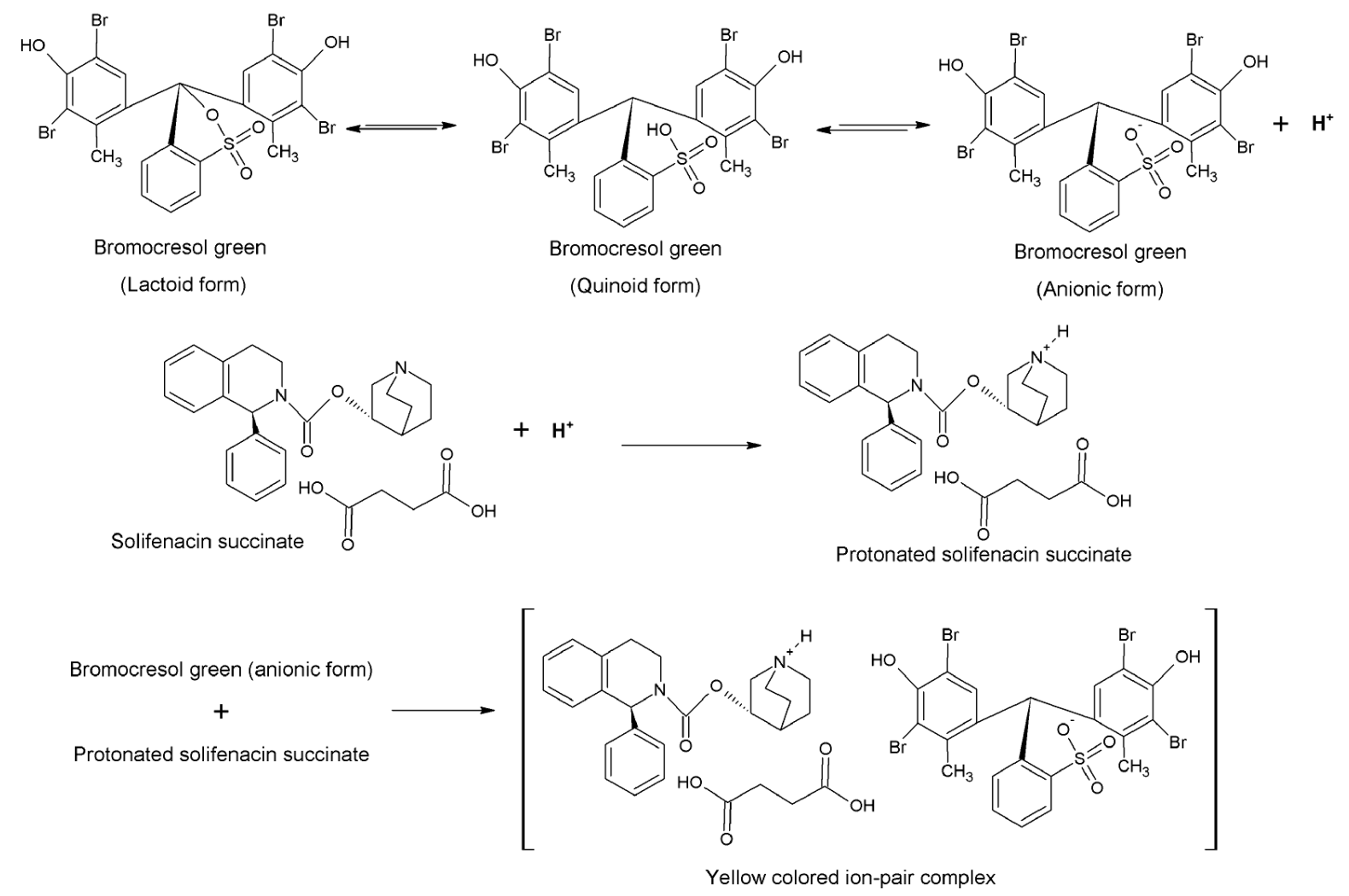

Fig. 5. Proposed reaction mechanism for the formation of SFS-bromocresol green ion-pair complex.

\section{3. 2. Method B}

The reaction was studied under various conditions of copper sulphate \& eosin concentration and extracting solvent. To study the influence of concentration of copper sulphate on the absorbance at $545 \mathrm{~nm}$, an aliquot of SFS containing $25 \mu \mathrm{g} / \mathrm{mL}$ was pipetted followed by varying volumes $(0.5-3.5 \mathrm{~mL})$ of $0.3 \%$ copper sulphate and $1 \mathrm{~mL}$ of $0.1 \%$ eosin. It was found that the increase in the volume of copper sulphate would increase the absorbance of the reaction product up to $2.5 \mathrm{~mL}$, after which there is stability in the absorbance of the reaction product. So $2.5 \mathrm{~mL}$ of $0.3 \%$ copper sulphate was found to be the appropriate concentration for maximum absorbance. To investigate the effect of concentration of eosin on the absorbance at $545 \mathrm{~nm}$, different volumes $(0.2-1.4 \mathrm{~mL})$ of $0.1 \%$ eosin were mixed with $1 \mathrm{~mL}$ of SFS $(25 \mu \mathrm{g})$ and $2.5 \mathrm{~mL}$ of $0.3 \%$ copper sulphate. The results reveal that the addition of $1 \mathrm{~mL}$ of eosin gave the highest absorbance, after which there is a decrease in the absorbance of the reaction product. Therefore, $1 \mathrm{~mL}$ of the $0.1 \%$ eosin was chosen as the suitable concentration for maximum absorbance. 
The effect of the extracting solvent on extraction efficiency and color intensity was investigated. Carbontetrachloride, acetonitrile, chloroform and dichloromethane were tested. Chloroform was selected for the extraction of ternary complexes formed in methods B and C. The use of chloroform as extracting solvent increased the stability of the extracted colored products in both methods $\mathrm{B}$ and $\mathrm{C}$ and considerably lowered extraction abilities of the reagent blank.

\subsection{Method C}

The reaction was studied under various conditions of ammonium molybdate, $\mathrm{HCl}$, ascorbic acid \& ammonium thiocyanate concentration, reaction time and extracting solvent.

The influence of ammonium molybdate concentration on the absorbance at $465 \mathrm{~nm}$ was investigated by adding various volumes $(0.5-4 \mathrm{~mL})$ of $0.001 \mathrm{M}$ ammonium molybdate to 1 $\mathrm{mL}$ of SFS $(50 \mu \mathrm{g} / \mathrm{mL})$. It is apparent that $2.5 \mathrm{~mL}$ of ammonium molybdate gave the maximum color intensity. Therefore, $2.5 \mathrm{~mL}$ of $0.001 \mathrm{M}$ ammonium molybdate was proved to be sufficient for the maximum color development.

The effect of acidity on the color development was studied by treating $1 \mathrm{~mL}$ of SFS (50 $\mu \mathrm{g} / \mathrm{mL})$ with varying volumes $(0.2-1.4 \mathrm{~mL})$ of $3 \mathrm{M} \mathrm{HCl}$. The absorbance at $465 \mathrm{~nm}$ was increased with increasing volume of $0.5 \mathrm{~N} \mathrm{HCl}$ and became constant at $1 \mathrm{~mL}$; above this volume, the absorbance remained unchanged. Thus a volume of $1 \mathrm{~mL}$ of $3 \mathrm{M} \mathrm{HCl}$ was preferred for the quantification process. The influence of the concentration of ascorbic acid on the intensity of the color developed at constant SFS concentration $(50 \mu \mathrm{g} / \mathrm{mL})$ was investigated in the range $0.2-1.4 \mathrm{~mL}$ of $10 \%$ ascorbic acid. The absorbance of colored complex at $465 \mathrm{~nm}$ was increased with increasing volume of ascorbic acid and became constant at $1 \mathrm{~mL}$. Beyond $1 \mathrm{~mL}$, the absorbance remained constant. Therefore, $1 \mathrm{~mL}$ of $10 \%$ ascorbic acid was recommended for the quantification process.

The effect of the concentration of ammonium thiocyanate on the color development was studied by adding different volumes $(0.5-3 \mathrm{~mL})$ of $10 \%$ ammonium thiocyanate to $1 \mathrm{~mL}$ of SFS $(50 \mu \mathrm{g})$. It was found that the absorbance at $465 \mathrm{~nm}$ was reached maximum with $2 \mathrm{~mL}$ of the ammonium thiocyanate, and remained constant with higher volumes. Therefore, $2 \mathrm{~mL}$ of the $10 \%$ ammonium thiocyanate was preferred as an optimum concentration.

To study the effect of reaction time for maximum color development, $1 \mathrm{~mL}$ of SFS (50 $\mu \mathrm{g}$ ) was mixed with $2.5 \mathrm{~mL}$ of $0.001 \mathrm{M}$ ammonium molybdate, $1 \mathrm{~mL} 3 \mathrm{M} \mathrm{HCl}, 1 \mathrm{~mL} 10 \%$ ascorbic acid solution and $2 \mathrm{~mL}$ of $10 \%$ ammonium thiocyanate.

The contents of the mixture were kept at room temperature for varied time. The maximum intensity of color was obtained at $10 \mathrm{~min}$ and remained constant up to $1 \mathrm{hr}$. Therefore, the optimum reaction time was fixed as $10 \mathrm{~min}$ throughout the experiment.

\section{3. 4. Method D}

The reaction was studied under various conditions of bromocresol concentration and diluting solvent. To investigate the effect of concentration of bromocresol green on the absorbance at $415 \mathrm{~nm}$, different volumes $(0.2-1.4 \mathrm{~mL})$ of $0.01 \%$ bromocresol green in dichlooromethane was mixed with $1 \mathrm{~mL}$ of SFS $(10 \mu \mathrm{g})$. The results reveal that the addition of $1 \mathrm{~mL}$ of bromocresol green gave the highest absorbance, after which there is a slight decrease in the absorbance of the reaction product. Therefore, $1 \mathrm{~mL}$ of the $0.01 \%$ bromocresol green in dichlooromethane was chosen as the suitable concentration for maximum absorbance.

In order to choose an appropriate solvent for preparation of the SFS standard and bromocresol green dye solutions, the standard and dye solutions were prepared separately in 
different solvents such as acetone, acetonitrile, chloroform and dichloromethane. The reaction of SFS with bromocresol green was followed. The results indicated that the dichloromethane was the suitable solvent for the preparation of SFS standard and bromocresol green dye solutions. In the same way, the effect of the diluting solvent was studied. The results showed that the same solvent, dichloromethane formed sensitive and stable colored product. Hence dichloromethane was used for dilution throughout the experimental process.

\section{4. Method validation}

The proposed methods (A, B, C and D) were validated according to $\mathrm{ICH}$ guidelines [33].

\section{4. 1. Linearity and Sensitivity}

After optimizing the experimental conditions, it was found that the relation between the absorbance and final concentration of SFS was linear over the range of $5-50 \mu \mathrm{g} / \mathrm{mL}$ (method A) $2.5-50 \mu \mathrm{g} / \mathrm{mL}$ (method B), $10-100 \mu \mathrm{g} / \mathrm{mL}(\operatorname{method} C)$ and $2-20 \mu \mathrm{g} / \mathrm{mL}(\operatorname{method} \mathrm{D})$. The linear regression analysis of the results gave the following equation:

Method A: $\mathrm{y}=0.0205 \mathrm{x}+0.0111\left(r^{2}=0.9995\right)$

Method B: $\mathrm{y}=0.0179 \mathrm{x}-0.0011\left(r^{2}=0.9993\right)$

Method C: $\mathrm{y}=0.0077 \mathrm{x}+0.0089\left(r^{2}=0.9991\right)$

Method D: $\mathrm{y}=0.0366 \mathrm{x}-0.0105\left(r^{2}=0.9992\right)$

where $\mathrm{y}=$ Absorbance; $\mathrm{x}=$ Concentration of drug in $\mu \mathrm{g} / \mathrm{mL} ; r^{2}=$ Regression coefficient.

The regression coefficient $(>0.99)$ values obtained indicate that there is a good correlation between absorbance and SFS concentration in all the proposed methods.

Molar absorptivity, sandell's sensitivity, limits of detection (LOD) and quantification (LOQ) are calculated as per the current ICH guidelines [33] to assess the sensitivity of the proposed methods. The results are summarized in Table 1. These results point out the excellent sensitivity of the proposed methods.

Table 1. Sensitivity of the proposed methods.

\begin{tabular}{|c|c|c|c|c|}
\hline \multirow{2}{*}{ Parameter } & \multicolumn{4}{|c|}{ Method } \\
\cline { 2 - 5 } & A & B & C & D \\
\hline Molar Absorbtivity $\left(\mathrm{L} \mathrm{mole}^{-1} \mathrm{~cm}^{-1}\right)$ & $1.105 \times 10^{5}$ & $8.649 \times 10^{4}$ & $3.748 \times 10^{4}$ & $1.609 \times 10^{5}$ \\
\hline $\begin{array}{c}\text { Sandell's sensitivity } \\
(\mu \mathrm{g} \mathrm{cm} / 2 / 0.001 \text { Absorbance unit })\end{array}$ & $4.34 \times 10^{-3}$ & $5.55 \times 10^{-3}$ & $1.28 \times 10^{-2}$ & $2.98 \times 10^{-3}$ \\
\hline LOD $(\mu \mathrm{g} / \mathrm{mL})$ & 0.101 & 0.116 & 0.322 & 0.081 \\
\hline LOQ $(\mu \mathrm{g} / \mathrm{mL})$ & 0.306 & 0.351 & 0.975 & 0.248 \\
\hline
\end{tabular}

\section{4. 2. Accuracy and Precision}

The accuracy and precision of the method was established by analyzing the pure SFS solution at 3 different concentration levels (within working limits) on the same day (intra-day accuracy and precision) and on three different days (intra-day accuracy and precision). The recovery (\%) \& relative error (\%) which is a measure of accuracy and SD \& RSD (\%) a 
measure of precision are summarized in Table 2. The results reveal the high accuracy and precision of the proposed methods.

Table 2. Accuracy and Precision of the proposed methods.

\begin{tabular}{|c|c|c|c|c|c|}
\hline \multirow{2}{*}{ Method } & \multicolumn{2}{|c|}{$\operatorname{SFS}(\mu \mathrm{g} / \mathrm{mL})$} & \multirow{2}{*}{ \% RSD } & \multirow{2}{*}{$\begin{array}{c}\% \\
\text { Recovery }\end{array}$} & \multirow{2}{*}{$\begin{array}{c}\% \\
\text { Error }\end{array}$} \\
\hline & Taken & Found $^{\mathrm{a}} \pm$ SD & & & \\
\hline \multicolumn{6}{|c|}{ Intra-day accuracy and precision } \\
\hline \multirow{3}{*}{$\mathbf{A}$} & 5 & $5.03 \pm 0.049$ & 0.974 & 100.60 & 0.60 \\
\hline & 25 & $24.96 \pm 0.215$ & 0.861 & 99.84 & 0.16 \\
\hline & 50 & $49.95 \pm 0.486$ & 0.972 & 99.90 & 0.10 \\
\hline \multirow{3}{*}{$\mathbf{B}$} & 2.5 & $2.48 \pm 0.012$ & 0.483 & 99.20 & 0.80 \\
\hline & 25 & $24.89 \pm 0.115$ & 0.462 & 99.56 & 0.44 \\
\hline & 50 & $50.03 \pm 0.324$ & 0.674 & 100.06 & 0.06 \\
\hline \multirow{3}{*}{$\mathbf{C}$} & 10 & $9.94 \pm 0.059$ & 0.593 & 99.40 & 0.60 \\
\hline & 50 & $49.96 \pm 0.491$ & 0.982 & 99.92 & 0.08 \\
\hline & 100 & $100.05 \pm 0.875$ & 0.874 & 100.05 & 0.05 \\
\hline \multirow{3}{*}{ D } & 2 & $1.98 \pm 0.016$ & 0.808 & 99.00 & 1.00 \\
\hline & 10 & $10.04 \pm 0.059$ & 0.587 & 100.40 & 0.40 \\
\hline & 20 & $19.93 \pm 0.142$ & 0.712 & 99.65 & 0.35 \\
\hline \multicolumn{6}{|c|}{ Inter-day accuracy and precision } \\
\hline \multirow{3}{*}{$\mathbf{A}$} & 5 & $5.01 \pm 0.052$ & 1.037 & 100.20 & 0.20 \\
\hline & 25 & $25.04 \pm 0.158$ & 0.63 & 100.16 & 0.16 \\
\hline & 50 & $49.97 \pm 0.378$ & 0.756 & 99.94 & 0.06 \\
\hline \multirow{3}{*}{ B } & 2.5 & $2.51 \pm 0.018$ & 0.717 & 100.40 & 0.40 \\
\hline & 25 & $25.02 \pm 0.140$ & 0.591 & 100.08 & 0.08 \\
\hline & 50 & $49.96 \pm 0.366$ & 0.732 & 99.92 & 0.08 \\
\hline \multirow{3}{*}{$\mathbf{C}$} & 10 & $10.04 \pm 0.063$ & 0.627 & 100.40 & 0.40 \\
\hline & 50 & $49.98 \pm 0.563$ & 1.126 & 99.96 & 0.04 \\
\hline & 100 & $100.03 \pm 0.924$ & 0.923 & 100.03 & 0.03 \\
\hline \multirow{3}{*}{ D } & 2 & $1.97 \pm 0.019$ & 0.974 & 98.50 & 1.50 \\
\hline & 10 & $9.96 \pm 0.082$ & 0.823 & 99.60 & 0.40 \\
\hline & 20 & $20.04 \pm 0.139$ & 0.693 & 100.20 & 0.20 \\
\hline
\end{tabular}

The accuracy of the proposed methods was further assessed by recovery studies. The recovery studies were carried out by the addition of known amount of standard SFS solution to preanalyzed tablet sample solution at three different concentration levels (50, 100 and 150 $\%$ level of the labeled claim). The resulting solutions were once again analyzed by proposed methods. The results of recovery studies are reported in Table 3. The percentage recoveries 
obtained reveal no interference from excipients commonly presented in pharmaceutical formulations and good accuracy of the proposed methods.

Table 3. Recovery data of the proposed methods

\begin{tabular}{|c|c|c|c|c|}
\hline \multirow{2}{*}{ Method } & \multicolumn{3}{|c|}{ Concentration of SFS (mg) } & \multirow{2}{*}{$\begin{array}{c}\% \\
\text { Recovery }\end{array}$} \\
\hline & Tablet & Spiked & Found $^{\mathrm{a}} \pm$ SD & \\
\hline \multirow{3}{*}{$\mathbf{A}$} & 5 & 2.5 & $7.48 \pm 0.068$ & 99.73 \\
\hline & 5 & 5 & $9.99 \pm 0.089$ & 99.90 \\
\hline & 5 & 7.5 & $12.52 \pm 0.101$ & 100.16 \\
\hline \multirow{3}{*}{ B } & 5 & 2.5 & $7.49 \pm 0.044$ & 99.86 \\
\hline & 5 & 5 & $9.97 \pm 0.067$ & 99.70 \\
\hline & 5 & 7.5 & $12.48 \pm 0.084$ & 99.84 \\
\hline \multirow{3}{*}{$\mathbf{C}$} & 5 & 2.5 & $7.46 \pm 0.081$ & 99.46 \\
\hline & 5 & 5 & $9.98 \pm 0.060$ & 99.80 \\
\hline & 5 & 7.5 & $12.52 \pm 0.078$ & 100.16 \\
\hline \multirow{3}{*}{ D } & 5 & 2.5 & $7.52 \pm 0.052$ & 100.26 \\
\hline & 5 & 5 & $9.98 \pm 0.086$ & 99.80 \\
\hline & 5 & 7.5 & $12.49 \pm 0.118$ & 99.92 \\
\hline
\end{tabular}

\section{4. 3. Stability of the colored products}

The effect of time on the stability of the colored products formed in methods A, B, C and $\mathrm{D}$ were studied by monitoring the difference in the absorption intensities at different time intervals after diluting the reaction mixture. The results show that absorption intensities values of the colored products were stable for at least $2 \mathrm{hrs}(\operatorname{method} \mathrm{A}), 1 \mathrm{hr} 30 \mathrm{~min}(\operatorname{method} \mathrm{B})$ and $1 \mathrm{hr}$ (methods $\mathrm{C}$ and $\mathrm{D}$ ). This gives the benefit of comfortable measuring at any time within that period with no changes in the values.

\section{4. 4. Robustness}

The robustness of the proposed methods was assessed by altering the following experimental conditions such as:

\section{Method A}

Volume of $0.0015 \mathrm{M} \mathrm{KMnO}_{4}(2.0 \pm 0.2 \mathrm{~mL})$

Volume of $0.6 \mathrm{M} \mathrm{NaOH}(2.0 \pm 0.2 \mathrm{~mL})$

Reaction time $(20 \pm 2 \mathrm{~min})$

\section{Method B}

Volume of $0.3 \%$ copper sulphate $(2.5 \pm 0.2 \mathrm{~mL})$

Volume of $0.1 \%$ eosin $(1.0 \pm 0.1 \mathrm{~mL})$

\section{Method C}


Volume of $0.001 \mathrm{M}$ ammonium molybdate $(2.5 \pm 0.2 \mathrm{~mL})$

Volume of $3 \mathrm{M} \mathrm{HCl}(1.0 \pm 0.1 \mathrm{~mL})$

Volume of $10 \%$ ascorbic acid $(1.0 \pm 0.1 \mathrm{~mL})$

Volume of $10 \%$ ammonium thiocyanate $(2.0 \pm 0.2 \mathrm{~mL})$

Reaction time $(10 \pm 2 \mathrm{~min})$

\section{Method D}

Volume of $0.01 \%$ bromocresol green $(1.0 \pm 0.1 \mathrm{~mL})$

The results are presented in Table 4. The good recoveries and low value of \% RSD shows that the proposed methods are robust. The deliberate small changes in the studied factors did not lead to a significant change.

Table 4. Robustness of the proposed methods

\begin{tabular}{|c|c|c|c|c|}
\hline \multirow{2}{*}{ Experimental condition } & \multicolumn{2}{|c|}{ Concentration of SFS $(\mu \mathrm{g} / \mathrm{mL})$} & \multirow{2}{*}{$\begin{array}{c}\% \\
\text { Recovery }\end{array}$} & \multirow{2}{*}{$\begin{array}{c}\% \\
\text { RSD }\end{array}$} \\
\hline & Taken & Found $^{\mathrm{a}}$ & & \\
\hline \multicolumn{5}{|c|}{ Method A } \\
\hline \multirow{2}{*}{$\begin{array}{c}\text { Volume of } 0.0015 \mathrm{M} \mathrm{KMnO}_{4}(2.0 \\
\pm 0.2 \mathrm{~mL})\end{array}$} & 5 & 4.95 & 99.00 & 0.828 \\
\hline & 50 & 49.93 & 99.86 & 0.514 \\
\hline \multirow{2}{*}{$\begin{array}{l}\text { Volume of } 0.6 \mathrm{M} \mathrm{NaOH} \\
(2.0 \pm 0.2 \mathrm{~mL})\end{array}$} & 5 & 5.03 & 100.6 & 0.834 \\
\hline & 50 & 49.96 & 99.92 & 0.696 \\
\hline \multirow{2}{*}{$\begin{array}{c}\text { Reaction time } \\
(15 \pm 2 \mathrm{~min})\end{array}$} & 5 & 5.03 & 100.60 & 0.516 \\
\hline & 50 & 49.95 & 99.90 & 1.049 \\
\hline \multicolumn{5}{|c|}{ Method B } \\
\hline \multirow{2}{*}{$\begin{array}{c}\text { Volume of } 0.3 \% \text { copper sulphate } \\
(2.5 \pm 0.2 \mathrm{~mL})\end{array}$} & 2.5 & 2.45 & 98.00 & 0.653 \\
\hline & 50 & 49.93 & 99.86 & 1.198 \\
\hline \multirow{2}{*}{$\begin{array}{l}\text { Volume of } 0.1 \% \text { eosin } \\
(1.0 \pm 0.1 \mathrm{~mL})\end{array}$} & 2.5 & 2.52 & 100.80 & 0.833 \\
\hline & 50 & 50.04 & 100.080 & 0.891 \\
\hline \multicolumn{5}{|c|}{ Method C } \\
\hline \multirow{2}{*}{$\begin{array}{l}\text { Volume of } 0.001 \mathrm{M} \text { ammonium } \\
\text { molybdate }(2.5 \pm 0.2 \mathrm{~mL})\end{array}$} & 10 & 10.04 & 100.40 & 0.517 \\
\hline & 100 & 99.98 & 99.98 & 0.492 \\
\hline \multirow{2}{*}{$\begin{array}{l}\text { Volume of } 3 \mathrm{M} \mathrm{HCl} \\
\quad(1.0 \pm 0.1 \mathrm{~mL})\end{array}$} & 10 & 9.96 & 99.60 & 0.682 \\
\hline & 100 & 99.94 & 99.94 & 0.586 \\
\hline \multirow{2}{*}{$\begin{array}{c}\text { Volume of } 10 \% \text { ascorbic acid (1.0 } \\
\pm 0.1 \mathrm{~mL})\end{array}$} & 10 & 10.05 & 100.50 & 0.388 \\
\hline & 100 & 100.03 & 100.03 & 0.463 \\
\hline \multirow{2}{*}{$\begin{array}{l}\text { Volume of } 10 \% \text { ammonium } \\
\text { thiocyanate }(2.0 \pm 0.2 \mathrm{~mL})\end{array}$} & 10 & 10.02 & 100.20 & 0.419 \\
\hline & 100 & 99.92 & 99.92 & 0.828 \\
\hline \multirow{2}{*}{$\begin{array}{l}\text { Reaction time } \\
(10 \pm 2 \mathrm{~min})\end{array}$} & 10 & 9.92 & 99.20 & 0.665 \\
\hline & 100 & 99.89 & 99.89 & 0.724 \\
\hline \multicolumn{5}{|c|}{ Method D } \\
\hline \multirow{2}{*}{$\begin{array}{c}\text { Volume of } 0.01 \% \text { bromocresol } \\
\text { green }(1.0 \pm 0.1 \mathrm{~mL})\end{array}$} & 2 & 2.01 & 100.50 & 0.597 \\
\hline & 20 & 19.94 & 99.70 & 0.822 \\
\hline
\end{tabular}

${ }^{\mathrm{a}}$ Average of three determinations

\section{5. Application}

The proposed methods were successfully applied to the assay of SFS in their dosage forms, Solicin tablets. Excellent recoveries with low RSD (\%) values were obtained. The results are tabulated in Table 5. Regular tablet excipients did not interfere with the assay in 
the four applied methods and therefore confirming that the developed methods are suitable for routine estimation of SFS in their pharmaceutical preparation.

Table 5. Determination of SFS in tablets by the proposed methods.

\begin{tabular}{|c|c|c|c|c|}
\hline \multirow{2}{*}{ Method } & \multicolumn{2}{|c|}{ Concentration of SFS (mg) } & \multirow{2}{*}{$\begin{array}{c}\text { \% } \\
\text { Recovery }\end{array}$} & $\begin{array}{c}\text { \% } \\
\text { RSD }\end{array}$ \\
\cline { 2 - 5 } & Tablet & Found $^{\mathrm{a}} \pm$ SD & & \\
\hline \multirow{2}{*}{ A } & 5 & $4.98 \pm 0.039$ & 99.60 & 0.781 \\
\cline { 2 - 5 } & 10 & $10.02 \pm 0.047$ & 100.20 & 0.469 \\
\hline \multirow{2}{*}{ B } & 5 & $5.02 \pm 0.029$ & 100.40 & 0.577 \\
\cline { 2 - 5 } & 10 & $9.96 \pm 0.049$ & 99.60 & 0.491 \\
\hline \multirow{2}{*}{ C } & 5 & $5.02 \pm 0.046$ & 100.40 & 0.916 \\
\cline { 2 - 5 } & 10 & $9.93 \pm 0.066$ & 99.30 & 0.664 \\
\hline \multirow{2}{*}{ D } & 5 & $4.97 \pm 0.048$ & 99.40 & 0.965 \\
\cline { 2 - 5 } & 10 & $9.96 \pm 0.063$ & 99.60 & 0.632 \\
\hline
\end{tabular}

${ }^{\mathrm{a}}$ Average of five determinations

\section{CONCLUSION}

In the present study, four spectrohotometric methods were developed and validated for the determination of solefenacin succinate in bulk and tablet dosage forms. The results of validation parameters reveal the good linearity, sensitivity, accuracy, precision and robustness of the proposed methods. The reagents used are easily available and economical. The proposed methods were successfully applied to tablet dosage forms. No interference was observed from regular pharmaceutical excipients.

\section{ACKNOWLEDGEMENTS}

One of the authors, B. S. V. Seshamamba is grateful to the Department of Food Chemistry and Nutrition, College of Food Science and Technology, Bapatla, and Department of Biochemistry, Acharya Nagarjuna University, Guntur for their continuous support \& encouragement and for providing the necessary facilities.

\section{References}

[1] Chapple C.R., Araño P., Bosch J.L., De Ridder D., Kramer A.E., Ridder A.M., BJU Int. 93 (2004) 71-77.

[2] Cardozo L., Lisec M., Millard R., Van Vierssen Trip O., Kuzmin I., Drogendijk T. E., Huang M., Ridder A. M., J. Urol. 172 (2004) 1919-1924.

[3] Ramandeep B., Con K., Ther. Clin. Risk. Manag. 4 (2008) 117-128.

[4] Wagg A., Wyndaele J. J., Sieber P., Am. J. Geriatr. Pharmacother. 4 (2006) 14-24. 
[5] Saroj Kumar R., Ravi Kumar B. V. V., Ajaya Kumar P., Int. J. Bioassays 1 (2012) 210-213.

[6] Rao K. N, Ganapaty S., Rao A. L., Pharmanest. 3 (2012) 366-374.

[7] Reddy B. V. R., Reddy B. S., Raman N. V. V. S. S., Reddy K. S., Rambabu C., J. Chem. 2013 (2013) Article ID 412353, 10 pages.

[8] Desai D., Patel G., Shukla N., Rajput S., Acta Chromatogr. 24 (2012) 399-418.

[9] Desai N., Hussen S. S., Vasanthraju S. G., Karthik A., Udupa N., Int. J. Pharm Pharma Sci. 3 (2011) 70-74.

[10] Krishna S. R, Rao B. M, Rao N. S., J. Chromatogr. Sci. 48 (2010) 807-810.

[11] Yanagihara T., Aoki T., Soeishi Y., Iwatsubo T., Kamimura H., J. Chromatogr. B, Analyt. Technol. Biomed. Life Sci. 859 (2007) 241-245.

[12] Macek J., Ptáček P., Klíma J., J. Chromatogr. B, Analyt. Technol. Biomed. Life Sci. 878 (2010) 3327-3330.

[13] Mistri H. N., Jangid A. G., Pudage A., Rathod D. M., Shrivastav P. S., J. Chromatogr. B, Analyt. Technol. Biomed. Life Sci. 876 (2008) 236-244.

[14] Desai J. D., Patel G., Ruikar D., Jain A. R., Rajput J. S., Asian J. Pharma. Bio. Res. 1 (2011) 310-316.

[15] Wankhede S. B., Kratika S., Chitlange S. S., Int. J. ChemTech Res. 3 (2011) 20032010 .

[16] Seetharaman R., Lakshmi K. S., Int. J. Res. Pharma. Biomed. Sci. 2 (2011) 10521057.

[17] Singh L., Nanda S., Pharm. Methods. 2 (2011) 21-24.

[18] Alia afra S., Rameeja S., Madhavi R., Venkataramanamma C., Divya G., Srilakshmi Y., Gobinath M., Saravanan D., Int. J. Res. Pharma. Sci. 4 (2013) 221-225.

[19] El-Fetouh Gouda A. A., El-Sheikh R., El- Shafey Z., Hossny N., El-Azzazy R., Int. J. Biomed. Sci. 4 (2008) 294-302.

[20] Kalsang T., Basavaiah K., Vinay K. B., Jordan J. Chem. 4 (2009) 387-397.

[21] Nagwa H. S. A., El-Hashemea E., El-Enany N., Belalb F., Arch. Appl. Sci. Res. 1 (2009) 1-11.

[22] Kumar J. V. S., Prasanthi S., Guravaiah M., Sekaran C. B., Asian J. Pharma. Clin. Res. 5 (2012) 18-22.

[23] Abdellatef H. E., Spectrochim. Acta. A, Mol. Biomol. Spectrosc. 66 (2007) 701-706.

[24] Magada M. A., Abdella A. S., Abdellatef H. E., J. Pharm. Biomed. Anal. 28 (2002) 311-321.

[25] Abdellatef H. E., Ayad M. M., Taha E. A., J. Pharm. Biomed. Anal. 18 (1999) 10211027.

[26] Ramadan A. A., Mandil H., Anal. Biochem. 353 (2006) 133-135.

[27] Kumar A. V. V. N. K. S., Saradhi S. V., Sekaran C. B., Reddy T. V., Chem. Sci. J. 2012 (2012) CSJ-47, 1-16. 
[28] Erk N., Anal. Lett. 36 (2003) 2699-2711.

[29] Cardoso S. G., Ieggli C. V. S., Pomblum S. C. G., Die Pharmazie. 62 (2007) 34-37.

[30] Li X. M., Chen Z. P., Wang S. P., Tang J., Liu C. Y., Zou M. F., Pharmazie. 63 (2008) 638-640.

[31] Chaple D. R., Bhusari K. P., Asian J. Chem. 22 (2010) 2593-2598.

[32] Ulu S. T., Aydogmus Z., Chem. Pharm. Bull. (Tokyo). 56 (2008) 1635-1638.

[33] Validation of Analytical Procedures; Methodology, International Conference on Harmonization (ICH): Text and Methodology Q2 (R 1): Complementary Guideline on Methodology dated 06 November 1996: incorporated in November 2005, London. 